\title{
DAMPAK CHANGE ORDER PADA PROYEK PERKERASAN JALAN
}

\author{
Alexander Junius ${ }^{1}$ dan Mega Waty ${ }^{2}$ \\ ${ }^{1}$ Program Studi Sarjana Teknik Sipil, Universitas Tarumanagara, Jl. Letjen S. Parman No.1 Jakarta \\ Email: alexander.325150124@stu.untar.ac.id \\ ${ }^{2}$ Program Studi Sarjana Teknik Sipil, Universitas Tarumanagara, Jl. Letjen S. Parman No.1 Jakarta \\ Email:mega@ft.untar.ac.id
}

Masuk: 16-01-2020, revisi: 17-02-2020, diterima untuk diterbitkan: 19-02-2020

\begin{abstract}
In a construction project, changes during the construction period are common. This change can be in the form of an increase or decrease in volume and type of work, changes in work specifications, or changes in the schedule for implementation. Changes in projects are often known as change orders. Change orders must be approved by all parties in a project namely, contractors, owners, and consultants. Change orders are caused by several factors such as changes in design, delays in procurement of goods, differences in field conditions, and others. The impact of this change order is felt by all parties involved in a project, but the change order has a different impact on each party involved. This study aims to determine the biggest impact of change orders from the contractor. In the questionnaire submitted the impact of change order is divided into several variables namely, the cost of quality, time, organization, and others. From the responses of respondents regarding the impact of change orders on road construction projects, an analysis was performed with the calculation of the Relative Importance Index (RII), and the biggest impact was obtained. Before the data is processed with RII, the validity and reliability tests are performed first. The biggest impact of change orders caused by change orders is that change orders increase the budget for contractors, change orders increase overhead costs, increase project duration, cause project costs overruns, and change orders cause a decrease in project profits.
\end{abstract}

Keyword: change order, impact change order, RII

\begin{abstract}
ABSTRAK
Pada suatu proyek konstruksi, perubahan selama masa konstruksi merupakan hal yang umum terjadi. Perubahan ini bisa berupa penambahan atau pengurangan volume dan jenis pekerjaan, perubahan spesifikasi pekerjaan, maupun perubahan jadwal pelakasnaan. Perubahan dalam proyek sering dikenal change order. Change order harus disetujui oleh semua pihak yang ada dalam suatu proyek, yaitu kontraktor, pemilik, dan konsultan. Change order disebabkan oleh beberapa faktor seperti perubahan desain, keterlambatan pengadaan barang, perbedaan kondisi lapangan, dan lain-lain. Dampak dari change order ini dirasakan seluruh pihak yang terlibat dalam suatu proyek, namun change order menimbulkan dampak yang berbeda pada tiap pihak yang terlibat. Penelitian ini bertujuan untuk mengetahui dampak change order terbesar dari pihak kontraktor. Dalam kuesioner yang diajukan dampak change order dibagi menjadi beberapa variabel yaitu, biaya mutu, waktu, organisasi, dan lainnya. Dari hasil tanggapan responden mengenai dampak change order pada proyek konstruksi jalan, dilakukan analisis dengan perhitungan Relative Importance Index (RII), dan didapat dampak terbesar. Sebelum data diolah dengan RII dilakukan uji validitas dan uji reliabilitas terlebih dahulu. Dampak change order terbesar yang ditimbulkan oleh change order adalah change order menambah anggaran untuk kontraktor, change order meningkatkan biaya overhead, menambah durasi proyek, menyebabkan biaya proyek membengkak, dan change order menyebabkan penurunan keuntungan proyek.
\end{abstract}

Kata kunci: change order, dampak change order, RII

\section{PENDAHULUAN}

Kegiatan proyek dapat diartikan sebagai satu kegiatan sementara yang berlangsung dalam jangka waktu terbatas, dengan alokasi sumber daya tertentu dan dimaksudkan untuk menghasilkan produk atau deliverable yang kriteria mutunya telah digariskan dengan jelas. Proyek konstruksi memiliki komponen kegiatan utama terdiri dari pengkajian kelayakan, desain engineering, pengadaan, dan konstruksi (Soeharto, 1999). Pada proyek konstruksi, baik proyek gedung, jalan, bendung, dan lain-lain memerlukan tahap perencanaan terlebih dahulu, dilanjutkan dengan pelaksanaan yang sesuai dengan desain dari tahap perencanaan. Namun dalam pelaksanaannya sering kali terjadi perubahan dari desain yang telah disepakati bersama pada tahap perencanaan. Hal ini bisa terjadi karena 
kesalahan pekerjaan di lapangan, maupun permintaan dari pemilik kepada pelaksana yaitu kontraktor. Perubahan ini bisa berupa penambahan atau pengurangan volume maupun pekerjaan. Perubahan selama konstruksi proyek tidak dapat dihindari dalam sebagian besar proyek konstruksi dan change order dikeluarkan untuk memperbaiki atau memodifikasi desain asli atau ruang lingkup pekerjaan (Alnuaimi, 2010).

Adendum adalah perjanjian antara pengguna jasa dan penyedia jasa, yang memuat perubahan-perubahan dalam pekerjaan atau dokumen kontrak yang mengakibatkan variasi dalam struktur harga satuan mata pembayaran atau variasi yang diperkirakan dalam jumlah harga kontrak dan telah dinegosiasi dan disepakati terlebih dahulu dalam perintah perubahan. (Dokumen Pelelangan Nasional Penyediaan Pekerjaan Konstruksi (Pemborongan) Untuk Kontrak Harga Satuan, Bab VII Spesifikasi Umum 2010, Revisi 3 Divisi 1, Pasal 1.13.1 ayat 1.b)

Pada proyek yang diselenggarakan pemerintah contract change order diatur pada pasal 87 Peraturan Presiden Nomor 54 Tahun 2010 yang berbunyi “ ayat 1 dalam hal terdapat perbedaan antara kondisi lapangan pada saat pelaksanaan, dengan gambar dan/atau spesifikasi teknis yang ditentukan dalam Dokumen Kontrak, PPK bersama Penyedia Barang/Jasa dapat melakukan perubahan pada Kontrak yang meliputi:

a. menambah atau mengurangi volume pekerjaan yang tercantum dalam kontrak;

b. menambah dan/atau mengurangi jenis pekerjaan;

c. mengubah spesifikasi teknis pekerjaan sesuai dengan kebutuhan lapangan; atau

d. mengubah jadwal pelaksanaan.

Perubahan Kontrak sebagaimana dimaksud pada ayat 1, berlaku untuk pekerjaan yang menggunakan kontrak harga satuan atau bagian pekerjaan yang menggunakan harga satuan dari kontrak gabungan lump sum dan harga satuan." Pada proyek pemerintah, perubahan pekerjaan yang dilakukan tidak boleh lebih dari $10 \%$ sesuai dengan pasal 87 Peraturan Presiden nomor 54 tahun 2010 ayat 2. Laporan Kantor Audit Nasional Taiwan 1998 menyatakan, kecacatan utama proyek pemerintah adalah banyaknya change order, yang menyebabkan proyek terlambat dan biaya membengkak (Hsieh, et al, 2004. Dalam beberapa kasus, change order menyebabkan kebingungan dan menyebabkan efek yang merusak lingkungan (Alnuaimi, 2010).

Kontrak konstruksi adalah kontrak yang sangat dinamis, memperjanjikan barang yang belum ada dan masih memerlukan proses untuk membentuk kontrak, sehingga harga kontrak akan selalu berubah dari waktu ke waktu, karena penyesuaian volume atau perubahan dalam metode pelaksanaan, baik yang dipesan oleh pengguna jasa melalui change order atau perubahan yang tidak diminta tetapi harus dilakukan untuk penyelesaian, Martanti (2018). Perubahan selama pembangunan proyek tidak dapat dihindari dalam sebagian besar proyek konstruksi dan change order dikeluarkan untuk mengoreksi atau memodifikasi desain asli atau lingkup pekerjaan (Alnuaimi, 2010). Perubahan pekerjaan ini dapat berupa penambahan, pengurangan, maupun penggantian pekerjaan.

Pengertian change order menurut Fisk \& Wayne(2010), adalah dokumen formal yang mengubah beberapa kondisi dokumen kontrak. Change order dapat mengubah harga kontrak, jadwal pembayaran, tanggal penyelesaian, atau rencana dan spesifikasi. Menurut Onkar (2010), change order adalah segala perintah berdasarkan kesepakatan yang diberikan kepada kontraktor oleh pemilik, agen pemilik, atau insinyur desain. Pengertian change order menurut Sulistio dan Waty (2008) adalah persetujuan tertulis untuk memodifikasi, menambah atau memberi alternatif pada pekerjaan yang telah diatur dalam dokumen kontrak antara pemilik dan kontraktor, dimana perubahan tersebut dapat dipertimbangkan untuk masuk dalam ruang lingkup proyek yang asli/ orisinil, dan merupakan satu-satunya cara yang sah.

Change order harus jelas, ringkas dan eksplisit. Change order harus memberi informasi kepada kontraktor mengenai apa yang harus diselesaikan, batas waktu dan tempat, kapan pekerjaan harus dilaksanakan, dan jika pekerjaan tersebut terpengaruh, bagaimana kontraktor akan dibayar dan pertimbangan apa saja yang akan diberikan terhadap waktu kontrak Terdapat 4 langkah dasar change order menurut Fisk \& Wayne, (2010):

1. Change order diajukan oleh kontraktor atau arsitek/insinyur kepada arsitek/insinyur dan pemilik.

2. Kontraktor mendiskusikan dan menyusun dokumen prosedur change order mengenai efek perubahan pada waktu dan biaya kontrak

3. Kontraktor mengajukan proposal change order yang ditandatangani kepada pemilik, menunjukkan semua biaya dan waktu tambahan yang diperlukan.

4. Pemilik menerima proposal dengan menandatangani proposal dan memerintahkan pelaksanaan pekerjaan yang dijelaskan.

Keane et al, (2010) mengelompokan penyebab change order menjadi 3 kategori berdasarkan pihak yang terkait kontrak, yaitu change order yang terkait dengan pemilik, kontraktor, dan konsultan.

1. Change order terkait pemilik dapat muncul karena perubahan cakupan, masalah keuangan pemilik, tujuan proyek yang tidak memadai penggantian dari bahan atau prosedur, hambatan proses pengambilan keputusan, pemilik yang keras kepala, dan perubahan spesifikasi oleh pemilik. Hal ini dijelaskan secara singkat sebagai berikut:

- Perubahan ruang lingkup 
- Masalah keuangan pemilik

- Tujuan proyek yang tidak jelas

- Penggantian bahan atau prosedur

- Hambatan untuk mempercepat proses pengambilan keputusan

- Sifat keras kepala pemilik

- Perubahan spesifikasi oleh pemilik

2. Change order terkait konsultan, konsultan dapat meminta variasi karena perubahan desain oleh konsultan, kesalahan atau kelalaian dalam desain, masalah pada dokumen kontrak, perubahan teknologi, rekayasa nilai, kurangnya koordinasi, kompleksitas desain, detail gambar kerja yang tidak memadai, pengetahuan yang buruk tentang bahan dan peralatan yang tersedia, kurangnya data yang dibutuhkan konsultan, detail desain yang ambigu, dan perubahan dalam spesifikasi oleh konsultan. Hal ini dijelaskan secara singkat sebagai berikut:

- Perubahan dalam desain oleh konsultan

- Kesalahan dan kelalaian dalam desain

- Masalah pada dokumen kontrak

- Perubahan teknologi

- Rekayasa nilai

- Kurangnya koordinasi

- Kompleksitas desain

- Detail gambar kerja yang tidak memadai

- Kurang pengetahuan tentang bahan dan peralatan yang tersedia

- Kurangnya data yang diperlukan konsultan

- Detail desain yang ambigu

- Desain yang tidak memadai

- Perubahan spesifikasi oleh konsultan

3. Change order terkait dengan kontraktor dapat terjadi karena kurangnya keterlibatan dalam desain, tidak tersedianya peralatan, kurangnya keterampilan, kesulitan keuangan kontraktor, profitabilitas yang diinginkan, perbedaan kondisi lapangan, pengerjaan yang buruk, tidak terbiasa dengan kondisi lokal, konstruksi jalur cepat, proses pengadaan yang buruk, kurangnya komunikasi, keterlambatan pengadaan, desain dan teknologi yang kompleks, dan kurangnya perencanaan strategis. Hal ini dijelaskan sebagai berikut:

- Kurangnya keterlibatan dalam desain

- Ketidaktersediaan peralatan

- Kurangnya keterampilan

- Kesulitan keuangan kontraktor

- Profitabilitas yang diinginkan

- Perbedaan kondisi lapangan

- Pengerjaan yang buruk

- Tidak terbiasa dengan kondisi lokal

- Konstruksi jalur cepat

- Proses pengadaan yang buruk

- Kurang komunikasi

- Keterlambatan pengadaan jangka panjang

- Desain dan teknologi yang kompleks

- Kurangnya perencanaan strategis

Keane et al, (2010), dampak change order dapat dikelompokkan dalam lima kategori: biaya,kualitas, waktu, efek terkait organisasi, dan efek lainnya

1. Efek yang berhubungan dengan biaya: Keterlambatan pembayaran dapat, mengarah ke peningkatan biaya proyek karena tarif bunga. Change order memerlukan prosedur pemrosesan, dokumen,dan ulasan sebelum dapat diimplementasikan, yang akan menyebabkan peningkatan biaya overhead. Pembayaran tambahan untuk kontraktor dapat menjadi efek potensial dari change order pada proyek konstruksi. Change order dianggap sebagai pekerjaan tambahan untuk kontraktor.

2. Efek terkait kualitas: Change order selama proyek dapat memengaruhi kualitas. Change order, jika sering, dapat menurunkan kualitas kerja. Change order dapat memengaruhi waktu penyelesaian proyek dan dapat menyebabkan percepatan proses konstruksi yang mempengaruhi kualitas.

3. Efek terkait waktu: Change order yang terjadi saat konstruksi sedang berlangsung atau bahkan selesai biasanya menyebabkan pengerjaan ulang dan keterlambatan penyelesaian proyek. Change order selama 
proyek dapat mempengaruhi kemajuan proyek, yang pada selanjutnya dapat mempengaruhi pembayaran kepada subkontraktor, biasanya karena kontraktor utama tidak dapat membayar sub kontraktor sampai mereka telah dibayar oleh pemiliknya sendiri. Keterlambatan jadwal penyelesaian adalah hal yang sering terjadi pada proyek konstruksi. Keterlambatan logistik dapat terjadi karena change order membutuhkan material dan peralatan baru.

4. Efek terkait organisasi: Perselisihan tentang change order dan klaim tidak bisa dihindari dan klausa change order sering menjadi sumber perselisihan dalam proyek. Perubahan konstruksi adalah sumber utama sengketa konstruksi. Change order pada akhirnya dapat memengaruhi hubungan profesional pada proyek konstruksi, yang mengarah ke perselisihan dan penundaan lebih lanjut. Klaim dan perselisihan dapat berdampak buruk pada reputasi perusahaan, dan juga dapat membuat perselisihan profesional lebih mungkin terjadi. Variasi dapat memengaruhi kondisi keselamatandalam proyek konstruksi. Change order mungkin membutuhkan metode dan tindakan pencegahan tambahan. Percepatan pekerjaan dapat menyebabkan kondisi keselamatan yang buruk. Selanjutnya, keterlambatan penyelesaian konstruksi, kegagalan dalam memenuhi persyaratan kualitas, dan meningkatnya resiko kecelakaan dapat merusak reputasi perusahaan, memburuknya hubungan profesional dan menyebabkan perselisihan di antara para profesional.

5. Efek lain: Change order dapat memengaruhi kemajuan proyek tanpa menyebabkan keterlambatan. Efek change order terkait waktu yang merugikan dapat dikompensasi dengan percepatan penyelesaian pekerjaan.

\section{METODE PENELITIAN}

\section{Kerangka Penelitian}

Kerangka penelitian yang digunakan sebagai pedoman alur penelitian dapat dilihat pada gambar 2.

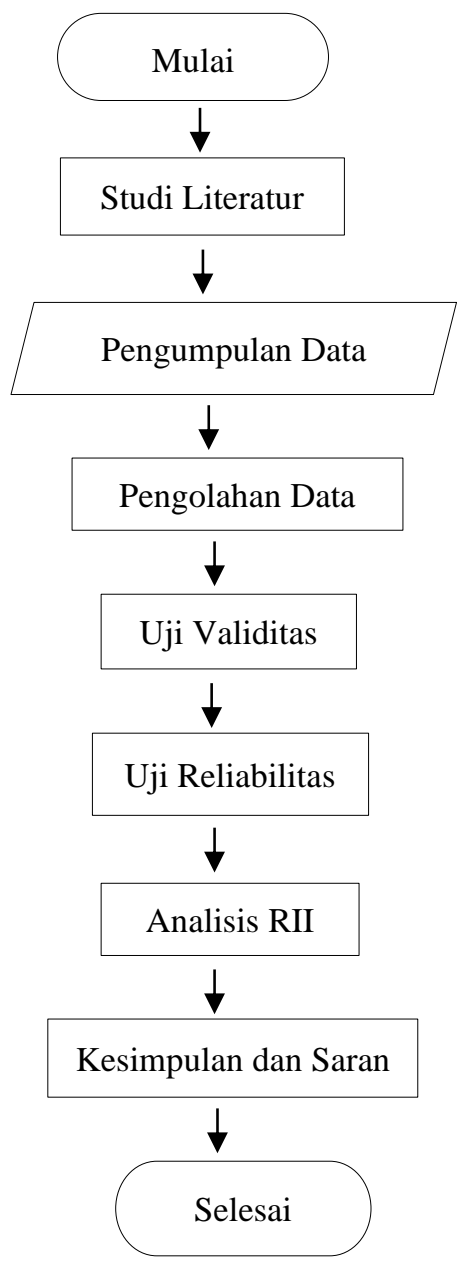

Gambar 1. Kerangka Penelitian 


\section{Studi Literatur}

Studi literatur dilakukan agar penulis dapat lebih memahami objek maupun metode yang akan diteliti. Studi literatur dilakukan melalui:

1. Buku-buku

2. Jurnal-jurnal

\section{Pengumpulan Data}

Pengumpulan data dilakukan dengan melakukan penyebaran kuesioner pada pihak-pihak yang pernah terlibat di proyek jalan di Jabodetabek. Kuesioner disebarkan ke kantor-kantor kontraktor yang pernah menanganin proyek jalan di Jabodetabek, maupun ke lokasi proyek jalan yang sedang berlangsung. Kuesioner digunakan untuk mengetahui dampak dari change order menurut kontraktor.

\section{Pengolahan Data}

Data yang berhasil dikumpulkan kemudian diolah dalam bentuk bagan Excel. Kemudian melakukan analisa dengan alat bantu statistik yaitu SPSS. Untuk menguji validitas dan reliabilitasnya.

\section{Uji Validitas}

Uji validitas digunakan untuk mengukur valid atau tidaknya suatu kuesioner, kuesioner akan dikatakan valid jika kuesioner tersebut bisa atau mampu mengukur obyek yang diukur.

\section{Uji Reliabilitas}

Dengan uji reliabilitas suatu penelitian akan diketahui bagaimana tiap pertanyaan dalam kuesioner saling berhubungan. Pengujian reliabilitas dilakukan dengan bantuan SPSS.

\section{Analisis RII}

Untuk pengukuran nilai kuesioner akan digunakan teknik pengukuran dengan skala likert yaitu berupa dampakdampak yang ditimbulkan akibat terjadinya change order pada proyek jalan, dengan skala pengukuran sebagai berikut : Keterangan untuk skala pengukuran tingkat frekuensi dampak change order pada proyek konstruksi :

1. Tidak pernah ada

2. Sangat Jarang

3. Jarang

4. Sering

5. Selalu ada

Dari hasil tanggapan dari koresponden mengenai dampak yang ditimbulkan akibat terjadinya change order pada proyek jalan maka dilakukan analisis perhitungan Relative Importance Index (RII) dengan rumus :

$$
\mathrm{RII}=\frac{\Sigma \mathrm{W}}{\mathrm{HS}}
$$

Dimana :

$\Sigma \mathrm{W}=$ bobot masing-masing faktor oleh responden mulai dari 1 sampai 5

$\mathrm{H}=$ bobot terbesar

$\mathrm{S}=$ jumlah dari tanggapan responden dari tidak pernah ada sampai selalu ada.

\section{HASIL DAN PEMBAHASAN}

\section{Karakteristik Responden}

Responden pada penelitian ini berjumlah 33 orang. Dengan pengalaman kerja 0-10 tahun berjumlah 20 responden, 11-20 tahun berjumlah 12 responden, dan 21-30 tahun berjumlah 1 responden. 


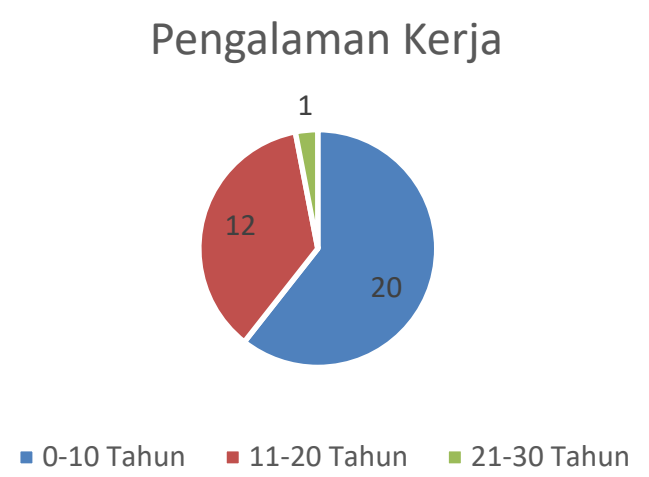

Gambar 2. Diagram karakteristik responden berdasarkan pengalaman kerja

\section{Uji Validitas}

Uji validitas dilakukan dengan cara statistik dengan SPSS. Variabel dikatakan valid jika nilai dari pearson corelation lebih besar dari nilai $r$ tabel.

Tabel 1 Hasil output SPSS uji validitas variabel mutu

\begin{tabular}{|c|c|c|c|c|}
\hline \multicolumn{5}{|c|}{ Correlations } \\
\hline & & $\begin{array}{c}\text { MUTU_ } \\
1\end{array}$ & $\begin{array}{c}\text { MUTU_ } \\
2\end{array}$ & TOTAL \\
\hline \multirow{3}{*}{$\underset{1}{\text { MUTU_ }}$} & Pearson Correlation & 1 & $.685^{* *}$ & $941^{* *}$ \\
\hline & Sig. (2-tailed) & &, 000 &, 000 \\
\hline & $\mathrm{N}$ & 33 & 33 & 33 \\
\hline \multirow{3}{*}{$\begin{array}{c}\text { MUTU_- }_{2} \\
\text { - }\end{array}$} & Pearson Correlation &, $685^{* *}$ & 1 &, $891^{* *}$ \\
\hline & Sig. (2-tailed) &, 000 & &, 000 \\
\hline & $\mathrm{N}$ & 33 & 33 & 33 \\
\hline \multirow{3}{*}{ TOTAL } & Pearson Correlation & ,941** &, $891^{* *}$ & 1 \\
\hline & Sig. (2-tailed) &, 000 &, 000 & \\
\hline & $\mathrm{N}$ & 33 & 33 & 33 \\
\hline
\end{tabular}

Dari hasil uji validitas menunjukan kuesioner valid karena hasilnya lebih besar dari nilai $r$ tabel. Nilai $r$ tabel untuk jumlah responden 33 adalah 0.3338

\section{Uji Reliabilitas}

Uji reliabilitas dilakukan dengan cara statistik dengan SPSS. Variabel dikatakan reliabel jika nilai dari cronbachs's alpha lebih besar dari 0,6.

Tabel 2 Hasil output SPSS uji reliabilitas variabel mutu

\begin{tabular}{c|c}
\hline \multicolumn{2}{c}{ Reliability Statistics } \\
\hline Cronbach's alpha & $\begin{array}{c}\mathrm{N} \text { of } \\
\text { Items }\end{array}$ \\
\hline 0,793 & 2 \\
\hline
\end{tabular}

Dari hasil uji reliabilitas menunjukan variabel reliabel, karena nilai Cornbach's Alpha lebih besar dari 0.6.

\section{Analisis RII}

Hasil analisis RII dapat dilihat pada tabel 3.3. Seteleh nilai RII diperoleh diurutkan dari yang terbesar untuk mencari dampak terbersar dari change order

Tabel 3 Peringkat dampak change order

\begin{tabular}{lccc}
\hline \multicolumn{1}{c}{ Biaya } & RII & Peringkat \\
\hline Change order menyebabkan biaya proyek membengkak & 0,6606 & 4 \\
\hline Change order menambah anggaran untuk kontraktor & 0,7091 & 1 \\
\hline Change order meningkatkan biaya overhead & 0,6788 & 2 \\
\hline Change order menyebabkan rework atau pekerjaan ulang & 0,5818 & 11 \\
\hline Change order menyebabkan penurunan keuntungan proyek & 0,6242 & 5 \\
\hline Change order mengganggu cash flow proyek & 0,6182 & 6 \\
\hline
\end{tabular}




\begin{tabular}{|c|c|c|}
\hline Mutu & & \\
\hline Change order menurunkan kualitas pekerjaan & 0,4545 & 15 \\
\hline Change order meningkatkan kualitas pekerjaan & 0,4303 & 17 \\
\hline \multicolumn{3}{|l|}{ Waktu } \\
\hline Change order menambah durasi proyek & 0,6667 & 3 \\
\hline Change order menyebabkan keterlambatan material & 0,6061 & 7 \\
\hline Change order menyebabkan keterlambatan peralatan kerja & 0,5879 & 10 \\
\hline Change order menghambat pekerjaan lain & 0,6000 & 9 \\
\hline Change order menyebabkan keterlambatan pembayaran & 0,6061 & 7 \\
\hline \multicolumn{3}{|l|}{ Organisasi } \\
\hline Change order menyebabkan sengketa dalam proyek & 0,5212 & 13 \\
\hline Change order menyebabkan penurunan performa dan moral pekerja & 0,4364 & 16 \\
\hline \multicolumn{3}{|l|}{ Lainnya } \\
\hline Change order menyebabkan pekerjaan yang dilakukan tidak sesuai prosedur & 0,4727 & 14 \\
\hline Change order menyebabkan penurunan produktifitas tenaga kerja & 0,5273 & 12 \\
\hline
\end{tabular}

\section{KESIMPULAN}

Dari hasil pengolahan data dengan RII dapat disimpulkan dampak change order dari keseluruhan variabel sebagai berikut :

1. Change order menambah anggaran untuk kontraktor

Change order menambah anggaran untuk kontraktor memiliki makna, anggaran atau dana yang perlu dipersiapkan untuk membayar kontraktor lebih besar, hal ini bisa terjadi dikarenakan penambahan volume pekerjaan, pekerjaan ulang, penambahan durasi proyek dan lain-lain.

2. Change order meningkatkan biaya overhead.

Change order pada proyek perlu divalidasi dan disepakati bersama oleh pemilik dan kontraktor. Perubahan perlu dikomunikasikan dan didokumentasi dengan baik kepada pihak-pihak yang terlibat. Oleh karena itu biaya diperlukan untuk dokumentasi hukum dan prosedur tertulis yang berkaitan perubahan tersebut.

3. Change order menambah durasi proyek

Change order menambah durasi proyek, hal ini memiliki makna change order menambah durasi penyelesaian proyek. Hal ini dapat terjadi karena penambahan volume pekerjaan, pekerjaan ulang, cuaca, kondisi lapangan, dan lain-lain.

4. Change order menyebabkan biaya proyek membengkak

Change order, memiliki banyak dampak pada proyek yang berkaitan dengan biaya, seperti penambahan biaya overhead, penambahan anggaran untuk kontraktor, dan lain-lain. Hal ini akan menambah biaya total penyelesaian proyek.

5. Change order menyebabkan penurunan keuntungan proyek

Change order dapat merusak produktifitas tenaga kerja. Biaya tenaga kerja proyek dapat meningkat dan memperlambat kemajuan proyek, memperpanjang jadwal dan meningkatkan biaya overhead. Total biaya proyek juga dapat meningkat, sehingga mengurangi keuntungan kontraktor.

\section{SARAN}

Setelah mengetahui dampak-dampak yang dapat ditimbulkan dari change order dalam sebuah proyek jalan, kontraktor dapat melakukan manajemen change order pada dampak-dampak terbesar yang terjadi pada tiap kategori responden, agar dampak-dampak yang tidak diinginkan dapat diminimalisir.

\section{DAFTAR PUSTAKA}

Alnuaimi, Ali S., et al. "Causes, Effects, Benefits, and Remedies of Change Orders on Public Construction Projects in Oman." Journal of Construction Engineering and Management, vol. 136, no. 5, 2010, pp. 615-22

Fisk, Edward. Construction Project Administration. 9th ed., Pearson, 2010.

Hardjomuljadi, Sarwono. Strategi Klaim Konstruksi Berdasarkan Fidic Conditions Of Contract. Pola Grade, 2006.

Hsieh, Ting-Ya., Lu, Shih-Tong., and Wu, Chao-Hui. "Statistical Analysis of Causes for Change order in Metropolitan Public Work". International Journal of Project Management, 22.p.679-686, 2004

Peraturan Presiden Republik Indonesia Nomor 54. Jakarta: 2010

Kementrian Pekerjaan Umum. Dokumen Pelelangan Nasional Penyediaan Pekerjaan Konstruksi (Pemborongan) Untuk Kontrak Harga Satuan. Jakarta: 2010 
Keane, Patrick, et al. "Variations and Change Orders on Construction Projects." Journal of Legal Affairs and Dispute Resolution in Engineering and Construction, vol. 2, no. 2, 2010, pp. 89-96

Martanti, Ana Yuni, and Sarwono Hardjomuljadi. "The Effect of Contract Change Order on Contractor Financing in Government Projects.” International Journal of Civil Engineering and Technology, vol. 9, no. 6, 2018, pp. $665-71$.

Onkar, Jadhav. "Review Analysis on Causes and Effects of Change Orders on Construction Projects." International Journal on Recent and Innovation Trends in Computing and Communication, vol. 3, no. 4, 2015, pp. $2230-33$. Soeharto, Iman. Manajemen Proyek (Dari Konseptual Sampai Operasional). 2nd ed., Erlangga, 1999.

Sulistio, Hendrik, and Mega Waty. "Analysis and Evaluation Change Order in Flexible Pavement (Case Study: Road Projects in East Kalimantan).” Media Komunikasi Teknik Sipil, vol. 16, no. 1, 2008, pp. 31-47, doi:10.14710/mkts.v16i1.3664. 